\title{
Interação em mídias sociais e socialização: algumas interfaces
}

\author{
Interaction in social media and socialization: some interfaces
}

Interacción en medios sociales digitales y socialización: algunas conexiones

Karina Marcon
Cristiane Koehler*

\section{Resumo}

Este artigo apresenta uma discussão sobre as tecnologias digitais de rede e as mídias sociais como dispositivos para um convívio sociointelectual entre os sujeitos em interação. Discutem-se os paradigmas comunicacionais de massa e de rede no contexto das mídias sociais, suas potencialidades para os processos comunicacionais, a abertura dos polos de emissão de mensagens e a possibilidade de o sujeito participar de forma mais efetiva nos processos comunicativos. Analisa-se a coexistência desses dois paradigmas comunicacionais em um contexto de convergência midiática, no qual as relações sociais acontecem com diferentes formatos de mídias, potencializando a interação social entre os sujeitos acerca dos conteúdos midiáticos decorrentes dessas inter-relações. Apresenta-se, ainda, o conceito de interação social em rede e sua atuação na natureza das relações entre os sujeitos envolvidos no sistema comunicacional, buscando exprimir como o processo comunicacional se constitui em um contexto de rede. A interação social em rede somente acontece em tecnologias digitais que disponibilizam recursos tecnológicos nos quais os sujeitos possam estabelecer conexões sociais.

Palavras-chave: mídias sociais; redes sociais; interação social; interação em rede.

\section{Abstract}

This article presents a discussion on digital network technologies and social media as devices for a social-intellectual conviviality between subjects in interaction. Mass and network communication paradigms are discussed in the context of social media, their potential for communicational processes, the opening of message emission poles and the possibility for the subject to participate more effectively in communicative processes. The coexistence of these two communicational paradigms is analyzed in a context of media convergence, in which social relations happen with different media formats, enhancing the social interaction between subjects about the media content resulting from these interrelations. It also presents the concept of social interaction in a network and its role in the nature of the relationships between the subjects involved in the communicational system, seeking to express how the communicational process is constituted in a network context. Social network interaction only occurs in digital technologies that provide technological resources in which the subjects can establish social connections.

Keywords: social media; social networks; social interaction; network interaction.

Recebido em: 30/07/2020 - Aprovado em: 16/12/2020

http://dx.doi.org/10.5335/rep.v28i1.12973

Mestre em Educação pela UPF; doutora em Educação pela UFRGS. Professora Associada da Universidade do Estado de Santa Catarina (Udesc); docente do Mestrado Profissional em Educação Inclusiva em Rede - Profei/Udesc. Orcid: https://orcid.org/0000-0002-3842-5296. E-mail: karina.marcon@udesc.br

* Mestrado em Ciência da Computação (UFSC). Doutorado e pós-doutorado em Informática na Educação (PGIE/ UFRGS). Professora Adjunta I da Universidade Federal de Mato Grosso (UFMT). Docente do Instituto de Educação, da área de Tecnologias Educacionais. Orcid: http://orcid.org/0000-0003-3685-0579. E-mail: cristiane.koehler@ufmt.br 


\section{Resumen}

Este texto se presenta una discusión sobre las tecnologías digitales de red y los medios sociales como dispositivos de convivencia socio-intelectual entre los sujetos en interacción. Se argumenta acerca de los paradigmas comunicacionales de masa y de red en el contexto de los medios sociales, sus potencialidades para los procesos comunicacionales, la apertura de los polos de emisión de mensajes y la posibilidad del sujeto participar de forma constante en los procesos comunicativos. Se analiza la coexistencia de estos dos paradigmas comunicacionales en un contexto de convergencia mediática, en el que las relaciones sociales ocurren con diferentes formatos de medios, potenciando la interacción social entre los sujetos sobre los contenidos mediáticos de estas interrelaciones. Se presenta, aún, el concepto de interacción social en red y su actuación en la naturaleza de las relaciones entre sujetos concernidos en el sistema comunicacional, buscando argumentar como el proceso comunicacional se constituye en un contexto de red. La interacción social en red sólo ocurre en tecnologías digitales que cuentan con recursos tecnológicos en los cuales los sujetos puedan establecer conexiones sociales.

Palabras-clave: medios sociales digitales; redes sociales; interacción social; interacción en red.

\section{Introdução}

O avanço tecnológico impulsionou uma transformação midiática, ocasionando novas formas de pensar e fazer comunicação. Em virtude da convergência entre as telecomunicações e os computadores houve uma ressignificação dos processos comunicativos, que deixam de ser unidirecionais e analógicos, reconfigurados por ações e sistemas que anulam a distância e o tempo, redimensionando a capacidade comunicacional e tornando o homem capaz de participar de processos comunicativos até então impensáveis (MARCON, 2008).

A partir do reconhecimento desse contexto social, Jenkins (2009, p. 29) nos coloca a pensar sobre a cultura da convergência, "[...] onde as velhas e as novas mídias colidem, onde mídia corporativa e mídia alternativa se cruzam, onde o poder do produtor de mídia e o poder do consumidor interagem de maneiras imprevisíveis”. Diferente do que acontecia com os meios de comunicação de massa, chamados por Jenkins (2009) de velhas mídias, percebemos que existe uma descentralização do poder midiático, antes concentrado nos produtores. Agora, produtores e consumidores articulam-se entre si, e não se faz mais mídia sem que o papel ativo do consumidor seja considerado.

O argumento de Jenkins (2009) é que a convergência não pode ser compreendida somente como um processo tecnológico que unifica múltiplas funções dentro dos mesmos aparelhos. "Em vez disso, a convergência representa uma transformação cultural, à medida que consumidores são incentivados a procurar novas informações e fazer conexões em meio a conteúdos de mídia dispersos" (JENKINS, 2009, p. 29-30). Em outras palavras, diz respeito principalmente à relação dos se- 
res humanos com os diferentes formatos de mídias e às interações entre os sujeitos acerca dos conteúdos midiáticos decorrentes dessas inter-relações.

Jenkins (2009) entende que a convergência não advém por meio de aparelhos, por mais sofisticados que sejam. A convergência acontece dentro do cérebro do consumidor individual e em suas interações sociais com outros. Considerando a expressão inteligência coletiva cunhada por Pierre Lévy, o autor propõe que o consumo se tornou um processo coletivo: "nenhum de nós pode saber tudo; cada um de nós sabe alguma coisa; e podemos juntar as peças, se associarmos nossos recursos e unirmos nossas habilidades. A inteligência coletiva pode ser vista como uma fonte alternativa de poder midiático" (JENKINS, 2009, p. 30).

Na concepção de Jenkins (2009), o pensamento convergente implica diretamente no remodelamento da própria cultura. Lemos (2003) já argumentava que o avanço tecnológico provocou um atravessamento das tecnologias na cultura contemporânea, caracterizando e impulsionando o desenvolvimento da cibercultura, ou seja, a cultura contemporânea marcada pela presença das tecnologias digitais de rede.

Essa nova dinâmica instituída pelas mídias digitais é totalmente diversa dos meios de comunicação analógicos. Kirkwood (2006) atenta que os sujeitos dispensam muito tempo criando conteúdos para sites e comunidades das quais fazem parte, mantém blogs, fazem filmes, disponibilizam links, escrevem resenhas, compartilham informações, formam comunidades. Ainda, a autora ressalta que eles fazem isso por vontade própria, unicamente através da sua motivação, para atestar, confirmar, estabelecer uma presença online e para desenvolver redes sociais e pertencer e participar de comunidades significativas. Podemos considerar isso como um movimento intensificado principalmente a partir da virtualização do conhecimento e da convergência midiática.

É a partir deste contexto que propomos neste trabalho a discussão sobre o potencial das mídias sociais para a socialização dos sujeitos, considerando que esses espaços de circulação social materializam a diversificação e alternância entre os papéis de emissão e recepção nos processos comunicativos. Para isso, em um primeiro momento estabelecemos diferenças entre dois paradigmas comunicacionais que coexistem, o paradigma das mídias de massa e o paradigma das redes. Na sequência, buscamos contextualizar as diferenças entre mídias sociais e redes sociais, para então trazer à discussão a interação social nos sites de redes sociais, bem como as relações que se estabelecem entre as mídias sociais e a socialização nesse contexto sociotécnico digital. 


\section{Paradigma comunicacional das mídias de massa e paradigma comunicacional das redes}

Por muito tempo, em relação à mídia, o ser humano esteve imerso em uma cultura de passividade e reprodução, uma vez que os processos tecnológicos e midiáticos existentes impossibilitavam uma participação mais efetiva do sujeito nos processos comunicativos. Por possuir um modelo comunicacional unidirecional, de um para todos, os processos de comunicação de massa são previamente estabelecidos dentro de uma estrutura comunicacional emissor-meio-mensagem-receptor, paradigma de transmissão de mensagens que busca atingir o maior número possível de pessoas.

Os meios de comunicação de massa (MCM) suportam processos de comunicação nos quais não há trocas nem interação entre os usuários e emissores das mensagens, e, uma vez que possuem grande alcance na audiência, procuram perpetuar a condição de consumidores aos sujeitos, seja de bens privados ou de concepções (CANCLINI, 2001). A comunicação midiática incita, entre produtos e serviços, estilos de vida, culturas e ideais. É nesse sentido que Canclini (1998, p.05) afirma que “[...] o rádio e a televisão se tornaram veículos de massa, desde meados do século, e homogeneizaram o desenvolvimento cultural, imprimiram seu estilo comunicativo a muitas interações sociais e se converteram no cenário decisivo para a constituição da vida pública”.

Para Stuart Hall (2003), a mensagem pode ter várias leituras e entendimentos porque, muito além da mensagem e seu real significado, existe um complexo eixo de percepções emocionais, ideológicas ou comportamentais, que se encontram entre a mensagem e seu receptor. Por mais que se saiba que a recepção de mensagens não é, em sua totalidade, passiva - uma vez que cada ser humano é singular e as interpreta de forma diferenciada (HALL, 2003) - é importante salientar que diante dos meios de comunicação de massa o indivíduo não possui interatividade, ou possui interatividade limitada. Nas mídias de massa, o feedback - canal de retorno - é restrito e não estimula a participação.

Apesar dos ruídos que podem existir entre o receptor e a mensagem destinada a ele, a mensagem pode modificar comportamentos e influenciar as pessoas. A todo instante os sujeitos são bombardeados por publicidade e propaganda nos meios de comunicação de massa e na internet, ofertando status, sensação de pertencimento, ideais, realização de sonhos e, desta forma, ampliando as portas para o consumo. 
Neste mesmo contexto, se por um lado os meios de comunicação de massa instituem um contexto de verticalidade e massificação, por outro as tecnologias de rede possuem potencial para uma ressignificação dessa lógica e dessa postura. Tal mudança é possível a partir do momento em que essas informações deixam de ser centralizadas, passando a ser de domínio de participação pública.

A internet, segundo Castells (2005), tem uma lógica reticular, e deve ser considerada uma revolução e não uma evolução dos suportes comunicacionais. Neste sentido, há a possibilidade do rompimento de um paradigma, que antes era vertical, passando para uma lógica reticular, em que se potencializam a autoria, a colaboração, a reflexão conjunta e crítica sobre as mensagens e a construção de caminhos de sistematização e contraposição das informações.

Surge, portanto, a necessidade de inclusão do cidadão nessa dinâmica das tecnologias de rede, mas numa perspectiva de rompimento com a lógica globalizada e mercantilista dos meios de comunicação de massa. Com as tecnologias de rede $o$ cidadão tem o potencial de participar, compartilhar, interagir, pois, dessa lógica de redes, emerge um processo diferenciado daquele apresentado até o momento, que potencializa espaços comunicativos até então inexistentes.

Ampliam-se as fontes de informação e rompe-se gradativamente com o poder antes exercido somente pelos meios de comunicação de massa. Castells (1999, p. 298-299) expõe que "[...] a explosão das telecomunicações e o desenvolvimento dos sistemas de transmissão a cabo viabilizaram o surgimento de um poder de transmissão e difusão de informações sem precedentes [...]".

Essas são características de uma sociedade que possui sua vivência ajustada pelas tecnologias digitais e que foi denominada por Castells como "sociedade em rede". O autor considera que a sociedade em rede é aquela "cuja estrutura social foi construída em torno de redes de informação a partir da tecnologia de informação microeletrônica estruturada na internet" (CASTELLS, 2005, p. 87). Nessa sociedade em rede, redimensionam-se todos os aspectos políticos, econômicos, sociais e culturais, uma vez que os mesmos são ressignificados pelas tecnologias digitais. A coletividade participa de um processo no qual as tecnologias são integrantes do seu desenvolvimento, pois caracterizam uma situação de "conectividade generalizada" (LEMOS, 2003) que atinge todos os setores, criando uma cultura de rede apresentada em diferentes manifestações.

Na linha de raciocínio traçada até aqui, surge, então, uma relação da sociedade com as tecnologias de rede, a chamada cibercultura, caracterizada como "a cultura contemporânea marcada pelas tecnologias digitais” (LEMOS, 2003). Poten- 
cialmente, permite o rompimento da verticalidade imposta durante muito tempo pelas mídias de comunicação de massa, possibilitando ao indivíduo a interação com processos comunicacionais que superam os meios convencionais de comunicação, pois potencializam a abertura dos polos de emissão de mensagem.

Aquele que, antes, era espectador, passa a interagir com os meios. As mesmas tecnologias que potencializam a dinâmica da globalização suportam essa nova configuração social denominada cibercultura. A cibercultura nasce com as tecnologias de rede, sendo fruto de um trabalho cooperativo em âmbito planetário. Nela há um livre e fácil acesso à informação, um processo que está em constante renovação. Diante disso, aponta-se para a relação das tecnologias digitais de rede com os diversos saberes, ou, como Lévy (2003, p. 28) menciona, com a inteligência coletiva, entendida como "uma inteligência distribuída por toda parte, incessantemente valorizada, coordenada em tempo real, que resulta em uma mobilização efetiva das competências". O autor complementa que esta é uma inteligência distribuída em toda a parte porque ninguém sabe de tudo, todos sabem de alguma coisa e todo o saber está na humanidade. Na coordenação das inteligências em tempo real, os acontecimentos, as decisões, as ações e as pessoas estariam situados nos mapas dinâmicos de um contexto comum, e transformariam, continuamente, o universo virtual em que adquirem sentido (LÉVY, 2003, p. 29).

Na dimensão da cibercultura, como aponta Lévy (2003, p. 30), "deixar de reconhecer o outro em sua inteligência é recusar-lhe sua verdadeira identidade social [...]". Frente a isso, é necessário salientar que essas potencialidades reticulares portadas pelas tecnologias de rede - nas quais há diferentes formas de troca de informações, de dados, de arquivos - possibilitam descentralizar o poder comunicacional que antes existia com os meios de massa e apontam caminhos para que essas inteligências individuais compartilhadas, constituam, efetivamente, a inteligência coletiva, pois não há detentores do conhecimento uma vez que ele se torna universal. Lemos (2004, p. 13) evidencia essa característica ao afirmar que:

A cibercultura, esse conjunto de processos tecnológicos, midiáticos e sociais emergentes a partir da década de 70 do século passado com a convergência das telecomunicações, da informática e da sociabilidade contracultural da época (Breton, 1990; Castells, 1996), tem enriquecido a diversidade cultural mundial e proporcionado a emergência de culturas locais em meio ao global supostamente homogeneizante. Uma das principais características dessa cibercultura planetária é o compartilhamento de arquivos, música, fotos, filmes, etc., construindo processos coletivos.

Nesse âmbito, a cibercultura propõe uma emergência das culturas locais em âmbito global. São esferas menores da sociedade que, agora, podem compartilhar 
informações e fazerem-se ver no tempo e no espaço mundial. O potencial da cibercultura possui uma reversão da lógica global centralizadora, pois os limites geográficos deixam de ser limitantes e condicionantes.

Essa desterritorialização proporcionada pela cibercultura possibilita diferentes trocas sociais, que são caracterizadas por diversos formatos de ambientes: fóruns, sites, blogs, sites de relacionamento, jogos eletrônicos, mídias sociais, sistemas de comunicação instantânea, entre outros. Independentemente de etnia, nacionalidade, cultura, sexo, idade, classe econômica ou qualquer outra característica que possa vir a tornar o ser humano excludente ou excluído, a cibercultura torna global o que antes era somente local. Os processos de territorializações, de acordo com Lemos (2007, p. 03), demonstram que:

A compressão do espaço-tempo institui o "tempo real" e a possibilidade de acesso a informações em todos os espaços do globo. O desencaixe nos permite vivenciar processos globais não enraizados na nossa tradição cultural. As mídias eletrônicas criam assim processos desterritorializantes em níveis político, econômico, social, cultural e subjetivo.

Essas mídias que desterritorializam possibilitam também a criação de novos territórios, em um processo de reterritorialização. Se "toda territorialização é uma significação do território (político, econômico, simbólico, subjetivo) e toda desterritorialização, re-significação, formas de combate à inscrição da vida em um 'terroir', linhas de fuga" (LEMOS, 2007, p. 04), a reterritorialização é a possibilidade que o sujeito tem, no ciberespaço, de encontrar algo que o remeta ao seu próprio território - através de blog, e-mail, sistema de posicionamento global (GPS) - enfim, qualquer situação na qual tenha referências e localização próprias.

O ciberespaço tem sua essência em uma lógica participativa e colaborativa de comunicação, que se dá através do contato, de trocas e de socialização. São milhares de pessoas que se constituem em nós da rede de comunicação, que têm a possibilidade de disponibilizar e produzir informações. Como revela Lévy (1999, p. 111), “[...] essa universalidade desprovida de significado central, esse sistema da desordem, essa transparência labiríntica, chamo-a de 'universal sem totalidade'. Constitui a essência paradoxal da cibercultura".

Esse novo espaço não está vinculado ao tempo e ao local, pois é instituído a partir da anulação das distâncias, que institui o tempo real. Para fazer parte do ciberespaço basta estar conectado à rede, uma vez que independe dos limites geográficos e temporais, desvinculando a necessidade da presença física para o estabelecimento de processos comunicacionais. Esse ambiente criado com a cibercultura potencializa a dinâmica cultural, como aponta Lemos (2004, p. 11): 
[...] a cibercultura potencializa aquilo que é próprio de toda dinâmica cultural, a saber o compartilhamento, a distribuição, a cooperação, a apropriação dos bens simbólicos. Não existe propriedade privada no campo da cultura já que esta se constitui por intercruzamentos e mútuas influências.

Com a liberação dos polos de emissão, uma das leis da cibercultura, segundo Lemos, o ser humano e as práticas comunicacionais potencializam-se a produzir nessas trocas sociais. Tais mudanças imbricam-se nas concepções vigentes sobre as estruturas e o funcionamento da subjetividade humana, sendo "[...] usuários interagentes de redes abertas e sem centro, nas quais 'os sujeitos se tornam cada vez mais instáveis, múltiplos e difusos”' (RÜDIGER, 2002, p. 100). É uma ação que pode ser considerada democrática frente ao decurso da globalização, que até então se presencia, tratando-se, talvez, de uma das facetas mais interessantes do processo. Como aborda Lemos (2004, p. 13):

A riqueza de qualquer sociedade sempre está ligada à complexidade de sua cultura, isto é, à força do seu poder criativo e empreendedor. A comunicação, neste sentido, é a forma pela qual uma sociedade põe em marcha e intercambia o conjunto de seus empreendimentos, sejam eles artísticos, sociais, políticos, científicos ou técnicos. Uma cultura complexa é uma cultura plural, aberta, circulando livremente pelo corpo social. A criatividade está na originalidade da circulação de diversas formas culturais, incluindo aí sua riqueza artística e intelectual, seu habitus social, sua criatividade simbólica, imaginária, científica e técnica.

Essas capacidades comunicativas que se expandem na cibercultura são resultados de processos que englobam múltiplas influências, daí o destaque reservado ao potencial da cibercultura em processos comunicativos, pois, efetivamente, há um amplo enriquecimento cultural e uma intensa troca de conhecimentos. Lemos (2007, p. 14-15) expõe claramente a ideia comunicacional da internet:

[...] menos do que uma nova mídia como os mass media (jornais, rádio, tv...), devemos pensar o ciberespaço como um ambiente midiático, como uma incubadora midiática onde formas comunicativas surgem a cada dia (chat, icq, fóruns, e-mail, blogs, web, etc.). A partir deste ponto de vista, podemos afirmar que o ciberespaço é, ao mesmo tempo, forma e conteúdo cultural, modulador de novas identidades e formas culturais.

Esse novo espaço de comunicação e interação surgido com a internet - e aqui denominado ciberespaço - ao lado dessas diferentes formas comunicacionais, potencializa o surgimento de processos interativos de tempo real, na qual a troca e a fusão de informações demonstram a diversidade e o potencial comunicacional que a rede possui. Esse processo de troca também é analisado por Lemos. Para o autor, como meio, 
[...] a internet problematiza a forma midiática massiva de divulgação cultural. Ela é o foco de irradiação de informação, conhecimento e troca de mensagens entre pessoas ao redor do mundo, abrindo o pólo da emissão. Com a cibercultura trata-se efetivamente da emergência de uma liberação do pólo da emissão (a emissão no ciberespaço não é controlada centralmente; todos podem emitir), e é essa liberação que, em nossa hipótese, vai marcar a cultura de rede contemporânea em suas mais diversas manifestações [...] (LEMOS, 2004, p. 15, grifo do autor).

$\mathrm{Na}$ internet não existe um controle sobre as informações, não há uma centralização, e tal situação é clara nesses espaços de interatividade. Todos são receptores e emissores, não havendo limites pré-estabelecidos para isso, o que demarca a cultura contemporânea, a cultura de rede, na qual o formato tradicional de comunicação - emissor-meio-mensagem-receptor - desestabiliza-se. As mídias sociais materializam, nesse contexto, essa diversificação e alternância entre os papéis de emissão e recepção nos processos comunicativos, discussão que aprofundaremos a seguir.

\section{Mídias sociais e redes sociais}

Desde que o surgimento da Web 2.0, temos acesso a uma infinidade de possibilidades comunicativas que até então não tínhamos conhecimento. Lemos (2010) já dizia que a Web 2.0 proporciona que os sujeitos deixem de ser apenas passivos diante de uma notícia, e passem a ser ativos, comentando, compartilhando, interagindo e publicando as suas ideias. Essa possibilidade de comunicação advinda dos recursos da Web 2.0 altera, significativamente, as interações sociais entre as pessoas simplesmente pelo fato de que deixamos apenas de consumir informações, passamos a produzi-las e a compartilhá-las.

Segundo Recuero (2009), os sites de redes sociais, também chamados de "redes sociais na internet", "websites de redes sociais", ou mais comumente, chamados de "mídias sociais", são sites disponíveis na Web 2.0 que possibilitam a criação de um perfil, com login e senha pessoal, em que os usuários podem encontrar pessoas e adicioná-las como uma conexão a sua rede social. Estes sites permitem a visualização do que as pessoas compartilham e a relação que as pessoas têm entre si, isto é, "quem é amigo de quem". Os usuários destes sites de redes sociais compartilham mensagens e todas as pessoas com as quais este usuário tem uma relação social no site poderão visualizar os seus compartilhamentos.

Recuero (2009, p. 102) explica que "os sites de redes sociais são os espaços utilizados para a expressão das redes sociais na internet”, porque é a partir destes 
sites que conseguimos visualizar a representação gráfica da nossa própria rede social. Boyd e Ellison (2007) afirmam que os sites de redes sociais são serviços baseados na Web que permitem aos indivíduos construir um perfil ou página pessoal que podem ser públicos ou privados. No entanto, os sites de redes sociais, também permitem articular uma lista de outros usuários com quem partilham uma mesma conexão e visualizar a rede social de outros usuários e a sua própria rede social. Isto é, a partir do momento em que criamos um perfil em um site de rede social, disponibilizamos a nossa própria rede social a qualquer outro usuário do site, bem como, podemos visualizar a rede social dos usuários com os quais mantemos alguma relação social. Qualquer usuário do site pode visualizar o nosso perfil, quem são os nossos amigos, os amigos que temos em comum e os amigos dos nossos amigos. Alguns sites oferecem opções de configurações de privacidade em que podemos limitar esta visualização, no entanto, o padrão é que estas informações estejam disponíveis para todos os usuários do site.

Os sites de redes sociais permitem que os usuários articulem as suas redes sociais e as tornem visíveis a todos os usuários. Isso pode resultar em conexões entre indivíduos que de outra forma não seriam feitas. Muitas vezes, os usuários de um site de rede social não têm necessariamente o objetivo de fazer novas conexões, mas de manter a comunicação com pessoas que já fazem parte da sua rede social. O perfil de um usuário em um site de rede social é uma página exclusiva daquele usuário, na qual, depois de criar o seu perfil, o usuário é convidado a informar alguns dados pessoais, como nome, idade, localização e interesses, e uma descrição pessoal. A maioria dos sites, também, incentiva os usuários a enviar uma foto de perfil. Por padrão, os perfis de um usuário são rastreados pelos motores de busca, do Google, por exemplo, tornando-os visíveis para qualquer pessoa, independentemente de quem pesquisa ter, ou não, um perfil no site, o perfil do usuário pesquisado aparece nas buscas do Google.

O site Linkedin disponibiliza informações adicionais aos usuários que pagam um valor mensal para ter acesso a informações que não são visíveis aos usuários não pagantes. $\mathrm{O}$ site Facebook, por exemplo, permite a visualização de todas as informações dos usuários com os quais temos uma relação de "amizade". No entanto, é possível configurar algumas opções de privacidade, em que escolhemos quais informações pessoais podem ser públicas, ou não.

Depois de aderir a um site de rede social, os usuários são solicitados a identificar parentes, amigos e conhecidos que também têm perfil no site e são incentivados a convidá-los a criar uma relação social no site. Esta relação social é identificada de 
diversas formas nos sites, como por exemplo, “amigos”, “contatos”, “fãs”, "seguidores”. A maioria dos sites exige a confirmação do outro usuário referente ao convite para estabelecer a relação social. Neste caso, a relação social é bidirecional, isto quer dizer que se um usuário aceitou o convite de outro usuário, os dois usuários passam a manter uma relação social entre si, tanto de um quanto do outro. Em outros sites a confirmação não é solicitada e esta relação, mesmo que estabelecida, é uma relação social unidirecional, isto é, apenas um usuário tem relação social com o outro. A exibição pública das relações sociais entre os usuários e os recursos que permitem o envio de mensagens privadas, são características importantes deste tipo de site (BOYD; ELLISON, 2007).

Sabemos que há uma variedade de sites de redes sociais, com diferentes recursos tecnológicos que atendem a objetivos diferentes, como por exemplo, o YouTube, Facebook, Twitter, Linkedin, Instagram, Pinterest, Tumblr, Snapchat, Periscope, entre outros. Estes sites possuem finalidades comuns, mas há sites com finalidades diferentes, como por exemplo, o Linkedin trata de ser uma rede exclusiva para manter contatos profissionais por meio da divulgação de vagas de trabalho, e o Twitter é um site que tem como objetivo a comunicação de mensagens curtas e que direcionam a leitura para outros sites. A cada instante, um novo site é disponibilizado na internet como mais um espaço virtual para a expressão de opiniões, ideias, compartilhamento de notícias e disseminação de informações.

Boyd e Ellison (2007) afirmam que a maioria destes sites são utilizados para manter as relações sociais existentes, mas que alguns sites ajudam pessoas que não se conhecem a se conectarem com base em interesses comuns. Os sites também diferem entre si na medida em que disponibilizam recursos de informação e comunicação diferenciados, tais como a possibilidade de conectividade a partir de dispositivos móveis e o compartilhamento de fotos, vídeos e áudios de tamanhos variados.

Os sites de rede social apresentam características e possibilidades de interações sociais que são comuns entre eles, no entanto, também há características que os diferem uns dos outros. Por exemplo, há sites em que a informação a ser compartilhada é, exclusivamente, uma imagem, como no caso do Instagram que prioriza o compartilhamento de fotografias, mas que possibilita o compartilhamento de vídeos com poucos segundos chamados de stories. Outros sites possibilitam o compartilhamento de informações a partir de diversos suportes tecnológicos, como imagens, vídeos, textos, parágrafos, e até arquivos, como o Facebook. Consideramos um suporte tecnológico ${ }^{1}$, todo recurso midiático que possibilita a visualização 
de uma informação, seja ela uma imagem, um texto, um vídeo ou um áudio e cada site possui especificidades quanto às possibilidades de compartilhamentos e tipos de interações possíveis.

Musso (apud SANTAELLA; LEMOS, 2010, p. 7) já afirmava que "a noção de rede é onipresente e onipotente em todas as disciplinas", isto é, o conceito de rede está presente nas mais variadas áreas do conhecimento e é imprescindível compreender o conceito de rede para saber o que se passa nos sites de redes sociais, as suas dinâmicas, como as informações se disseminam na internet, e como as ideias e atitudes dos amigos, dos amigos, dos nossos amigos, nos influenciam (CHRISTAKIS; FOWLER, 2010).

Nesse momento é importante sabermos que mídias sociais não é o mesmo que redes sociais e por isso é importante conhecermos o conceito de redes sociais. Para Wasserman e Faust (1994, p. 20), "uma rede social consiste de um conjunto finito de atores e as relações definidas entre eles" e que estas conexões podem ser de três tipos: relação social, interação social e laço social. Conceituam rede social como toda estrutura social que envolve indivíduos que partilham dos mesmos interesses e afirmam que as redes sociais são representadas graficamente por sociogramas ${ }^{2}$, que são grafos com nós indicando atores e arestas representando as conexões entre estes atores e são recursos utilizados para determinar a sociometria ${ }^{3}$ de um espaço social.

Dos três tipos de conexão social em uma rede social, discutiremos a seguir o tipo de conexão denominado de interação social que representa a comunicação social entre os sujeitos em uma mídia social.

\section{Interação social}

A comunicação que ocorre nos sites de redes sociais é denominada de interação social. Essa interação social ocorre entre os sujeitos de forma síncrona e/ou assíncrona, isto é, em tempo real (online), e/ou em outro tempo (offline). Segundo Primo (2003, p. 97), a interação é “uma série complexa de mensagens trocadas entre os sujeitos", e o autor ainda define dois tipos de interação: mútua e reativa.

A interação mútua é a comunicação entre duas pessoas criada pela ação de ambas. Onde uma comunica-se com a outra e as duas comunicam-se entre si (são as ações entre duas pessoas). Trata-se, da inter + ação criada pela ação de ambas. Isto é, a cada encontro, as ações de uma definem (ou redefinem) a relação entre elas (PRIMO, 2003, p. 97). 
O autor afirma que a diferença entre a interação mútua e a interação reativa é que a primeira constitui uma relação recíproca de trocas entre os atores envolvidos no processo de comunicação. E, a segunda, as relações não se constituem. Neste caso, é constatada uma comunicação unidirecional, em que somente um dos atores age e os outros atores apenas recebem a mensagem sem interferir na comunicação, nem na mensagem. O autor compreende que a interação é a "ação entre" e que a comunicação é "ação compartilhada". Em uma interação mútua, os atores transformam-se mutuamente durante o processo, e a relação que emerge entre eles vai sendo recriada a cada troca. $\mathrm{O}$ autor ainda afirma que nesse tipo de interação é possível se prever o que vai acontecer porque todo o encaminhamento da relação é negociado durante a interação. Ao interagirem, um modifica o outro. Na interação reativa, as interações são limitadas pelo fato de que apenas um ator comunica-se com o outro. A comunicação não tem duplo sentido, e o autor adota as palavras "relação" e "relacionamento", como sinônimas.

O conceito de interação possui várias definições, nas mais diversas áreas do conhecimento e na perspectiva de diversos autores. A interação social neste trabalho é estudada à luz dos autores Watzlawick, Beavin e Jackson (2000), Cooley (1975), Parsons e Shill (1975), Reid (1991), Silva (2010) e Primo (2003).

Watzlawick, Beavin e Jackson (2000) explicam que a interação representa um processo sempre comunicacional. A interação é, portanto, aquela ação que tem um reflexo comunicativo entre o indivíduo e seus pares, como reflexo social. Os autores entendem que a interação atua diretamente sobre a definição da natureza das relações entre aqueles envolvidos no sistema interacional. A interação, pois, tem sempre um caráter social perene e diretamente relacionado ao processo comunicativo.

Para Parsons e Shill (1975), as interações são parte das percepções do universo em que os atores estão inseridos influenciadas por elas e pelas motivações particulares desses atores. Segundo Silva (2010), o conceito de interação foi transmutado, na área da informática, para o termo "interatividade". O autor faz uma discussão sobre o uso indiscriminado do conceito de interação como argumento de venda e aponta que:

[...] nos debates acadêmicos em que o conceito de interatividade é colocado em questão, encontro frequentemente, pelo menos duas críticas. Uma considerando-o como argumento de venda próprio da nova era tecnológica marcada pela indústria informática. Outra enfatizando que o termo interatividade não diz nada além do que já diz o termo interação (SILVA, 2010, p. 110). 
De acordo com Reid (1991), a interação social, no âmbito do ciberespaço, pode dar-se de forma síncrona ou assíncrona, isto é, se a comunicação é em tempo real ou não, respectivamente. Dependendo dos recursos disponíveis, são possíveis as duas formas de comunicação na internet como, por exemplo, o envio de mensagens de forma síncrona (em tempo real) para amigos que estão online naquele determinado instante; e mensagens assíncronas que serão lidas quando o usuário estiver online.

Para Cooley (1975), a comunicação compreende o mecanismo último das interações sociais. Estudar a interação social compreende, desse modo, estudar a comunicação entre os atores. Estudar as relações entre suas trocas de mensagens e o sentido das mesmas, estudar como as trocas sociais dependem, essencialmente, das trocas comunicativas.

Segundo Koehler (2016), a comunicação que acontece em um site de rede social foi denominada como interação social em rede e nas redes que será discutida na próxima seção.

\section{Interação social nos sites de redes sociais}

A comunicação entre usuários de sites de redes sociais é uma comunicação que acontece em um ambiente de rede social na internet, e que denominamos de interação social em rede e nas redes. Esta comunicação é assim denominada porque entendemos que a comunicação mediada pelo computador, que se utiliza de sites de redes sociais, possibilita o tipo de conexão social denominada de interação social. No entanto, não é qualquer interação social que se constitui em um site de rede social. Esta interação social é uma interação que acontece a partir de uma rede de relações sociais, e por isso, a denominação de interação social em rede e nas redes (KOEHLER, 2016).

Estas interações sociais em rede constituem-se em uma comunicação coletiva, pública e permanente, isto é, coletiva porque acontece em um ambiente de rede; pública porque é visualizada por todas as conexões sociais do usuário; e permanente porque permite a recuperação de parte da comunicação ao longo do tempo. São interações sociais diferentes daquelas que acontecem comumente na internet, justamente porque emergem de um site de rede social que é coletivo, público e compartilhado por dezenas, centenas ou milhares de outros usuários. São interações sociais que se utilizam das conexões estabelecidas entre os usuários no site de rede social para se espalhar entre outros usuários. 
A interação social em rede e nas redes emerge da união de várias redes sociais ${ }^{4}$ das quais os usuários fazem parte. São capazes de levar milhares de pessoas a assistirem um vídeo no YouTube, de influenciarem eleições presidenciais, de refletir tendências, de levar centenas de pessoas a comprarem um determinado produto e de se organizarem publicamente para ajudar pessoas vítimas de alguma tragédia. A partir destas interações sociais que acontecem em rede e nas redes, movimentos sociais são organizados, estruturados, disseminados e conduzidos em todo mundo. São, fundamentalmente, interações amplificadas, emergentes e complexas que surgem da interconexão entre os usuários que fazem parte de um mesmo site de rede social. E é esse tipo de interação social que emerge nos sites de redes sociais que apresentamos neste trabalho.

A disseminação de diversos tipos de sites de redes sociais resultou em novas formas de comunicação e interação entre as pessoas. Recuero, Bastos e Zago (2015) afirmam que "os sites de redes sociais permitiram às pessoas publicar e ampliar suas redes, criando novas conexões e novas formas de circulação de informação". No entanto, sabemos que foi muito mais do que isso, estes sites de redes sociais proporcionam uma comunicação coletiva, em tempo real (síncrona) ou não (assíncrona), pública e capaz de atingir um número expressivo de pessoas.

As interações sociais em rede e nas redes diferenciam-se dos demais tipos de interação social no espaço digital porque são constituídas dentro de um ambiente que organiza e que representa as redes sociais reais. São interações capazes de "circular" pelas conexões sociais dos usuários, espalhando-se para outros grupos sociais, e para outros espaços dentro do site de rede social. São interações que fazem as informações circularem entre as diversas redes sociais dos usuários, emitindo e recebendo novidades, mas que não necessariamente são informações compartilhadas entre usuários conectados entre si. Isto é, são interações que disseminam informações de outros usuários que não são suas conexões diretas, são os amigos, dos amigos, dos seus amigos (CHRISTAKIS; FOWLER, 2010). Sendo assim, são interações sociais que surgem entre alguns usuários e que vão sendo disseminadas na rede pelas conexões sociais que estes usuários possuem.

A interação social em rede e nas redes surge nos sites de redes sociais justamente porque estes sites possuem os recursos e funcionalidades que permitem a comunicação em rede. São comunicações que não estão restritas a um ou dois usuários, ou a pequenos grupos de usuários, mas são comunicações que extrapolam os limites destes, e ampliam o seu alcance a outras redes sociais. Por isso, as interações sociais em rede são potencializadas pelos sites de redes sociais que 
facilitam a comunicação não apenas de usuários que são da mesma rede social, mas também, de usuários que fazem parte de outras redes sociais. Qualquer usuário de um site de rede social tem muito mais possibilidades de estar em contato com pessoas de redes sociais desconhecidas, do que se este usuário não tivesse um perfil no Facebook, por exemplo. Estes sites potencializam as redes sociais já existentes e facilitam o acesso a novas redes sociais.

A interação social em rede e nas redes é possibilitada pelos recursos e funcionalidades que o site de rede social dispõe. Por exemplo, o Facebook oferece os recursos de "curtir", "comentar", “curtir comentário", "visualizar", "cutucar”, “compartilhar" e "chat" como tipos de interação social em rede. São recursos que o Facebook oferece aos usuários para comunicarem-se na rede. Quando um usuário usar um destes recursos, todas as suas conexões, receberão nas suas "linhas do tempo" a informação de que aquele usuário curtiu, comentou, compartilhou, etc. alguma informação.

A interação social em rede também torna público as relações sociais construídas entre os usuários apresentando "quem é amigo de quem" e "quem são os amigos em comum", como é possível visualizar no Facebook. Outra característica da interação social em rede é a possibilidade de fazer com que uma informação seja "espalhada" entre diversas redes sociais com apenas um clique.

Compreendemos que a interação social em rede se constitui a partir da metáfora da rede, ou seja, "as redes são metáforas estruturais para os grupos humanos, onde se procura compreender as suas inter-relações" (RECUERO, 2014, p. 127128). Neste sentido, “os sites de redes sociais são metáforas para esses grupos na mediação do computador" (RECUERO, 2009, p. 56). Em outras palavras, Recuero (2014, p. 128) diz que "as redes sociais ficam explícitas no site de rede social a partir das interações sociais que emergem entre os usuários”, e que "as conexões são os elementos mais complexos das redes sociais porque são as conexões que unem os usuários em grupos sociais" (RECUERO, 2014, p. 128-129). Compreendemos a interação social em rede como a comunicação síncrona e/ou assíncrona entre tríades, que é a comunicação no mínimo entre três atores.

A Figura 1 mostra a composição de uma tríade representada em um grafo direcionado. É importante salientar que a Teoria dos Grafos, de Leonard Euler, oferece o embasamento teórico e matemático para a compreensão das redes sociais e das suas propriedades. 
Figura 1 - Grafo que representa uma tríade

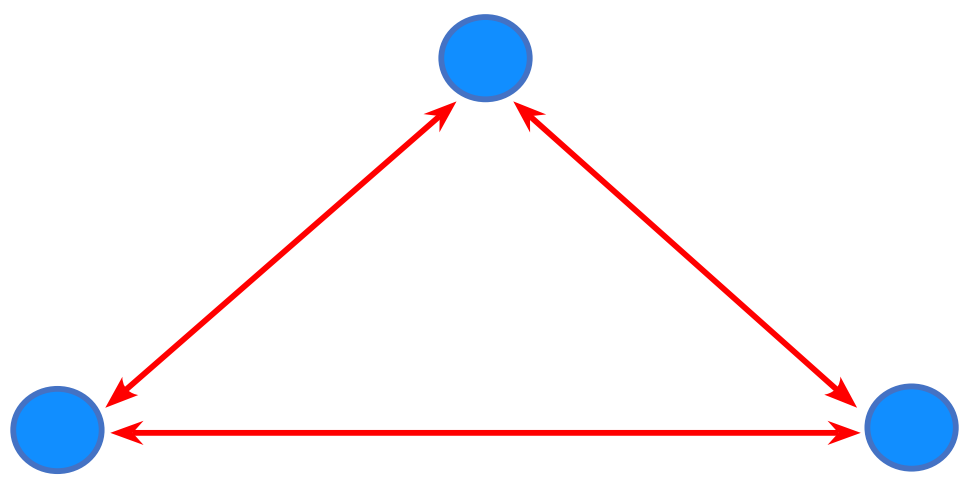

Fonte: Koehler (2016, p. 83).

Compreendemos a interação social em rede e nas redes como sendo as diversas formas que os usuários têm para se comunicarem em um site de rede social. A seção seguinte apresenta uma discussão sobre como as mídias sociais colaboram para com convívio sociocultural entre os sujeitos em interação.

\section{Sociedade em rede, redes sociais e socialização}

De acordo com Capra (2002, p. 93), o padrão em rede - network pattern - é um dos padrões de organização mais básicos de todos os sistemas vivos. Conforme o autor, em todos os níveis de vida - desde as redes metabólicas das células até as teias alimentares dos ecossistemas -, os componentes e os processos dos sistemas vivos se interligam em forma de rede. Diante disso, foi feita uma aplicação da compreensão sistêmica da vida - em específico em relação à compreensão das redes - ao domínio social.

Com isso, a sociedade passou a ser analisada sob esse viés das redes principalmente a partir dos estudos do sociólogo Castells (2005). Capra (2002, p. 94) explica que as redes sociais são, antes de mais nada, “[...] redes de comunicação que envolvem a linguagem simbólica, os limites culturais, as relações de poder e assim por diante". É uma situação que envolve todos os setores da sociedade, pois tudo acaba sendo interligado através das teias da rede.

Capra (2002, p. 96) explicita essa forma de organização mencionando que "[...] para interpretar alguma coisa, nós a situamos dentro de um determinado contexto de conceitos, valores, crenças ou circunstâncias". O autor ainda continua: "para compreender o significado de alguma coisa, temos de relacioná-la com outras coisas 
no ambiente, no seu passado ou no seu futuro. Nada tem sentido em si mesmo". Portanto, todas as experiências, os fatos, as situações vivenciadas são automaticamente relacionadas a outras que interligam toda a conjuntura da sociedade contemporânea, em um processo que é cíclico e nada constante, pois como o próprio autor menciona, a rede social é "um padrão não linear de organização" (CAPRA, 2002, p. 93).

Assim, por entender que "a tecnologia é uma das características que definem a natureza humana: sua história se estende por todo o decorrer da evolução do ser humano" (CAPRA, 2002, p. 97), é preciso reconhecer que elas sempre possuíram e - mais do que nunca - possuem estreitas relações com a sociedade. Desde os primeiros utensílios criados para auxiliar o homem em seu cotidiano até os cabos de fibra ótica da atualidade, tudo é tecnologia, o que acabou por criar uma situação de extrema relação entre o homem e ela (MARCON, 2008).

Portanto, frente a essa "nova compreensão da vida [...]" (CAPRA, 2002, p. 97), acredita-se que as tecnologias de rede acabam potencializando essa estrutura social, pois através delas a rede - em âmbito mundial - acontece, pois inexistem as barreiras do tempo e do espaço, já mencionadas anteriormente neste estudo. As TDR criam cada vez mais possibilidades e alternativas para que todos os pontos do mundo se conectem através da rede, instituindo, assim, essa sociedade em rede.

Diante disso, Castells (2005, p. 276) menciona que:

[...] mais que ver a emergência de uma nova sociedade, totalmente on line, o que vemos é a apropriação da Internet por redes sociais, por formas de organização do trabalho, por tarefas, ao mesmo tempo que muitos laços fracos, que seria demasiadamente complicados de manter off line, podem ser mantidos on line.

A internet potencializa as redes sociais, contribuindo para o estreitamento e fortalecimento das próprias relações sociais. Nesse sentido, na contemporaneidade, Castells (2005, p. 256) considera que "[...] a internet é - e será ainda mais - o meio de comunicação e de relação essencial sobre o qual se baseia uma nova forma de sociedade que já vivemos", aquela que o autor chama de sociedade em rede.

Para Castells (2005, p. 287), internet é sociedade porque expressa os processos sociais, os interesses sociais, os valores sociais, as instituições sociais. O próprio autor se questiona sobre qual é, então, a especificidade da Internet se ela é sociedade? Para o autor, a especificidade é que ela constitui a base material e tecnológica da sociedade em rede. A internet é a infraestrutura tecnológica e o meio organizativo que permite o desenvolvimento de uma série de novas formas de relações sociais e socialização. Essas relações sociais não têm sua origem na Internet, sendo frutos 
de uma série de mudanças históricas, elas jamais poderiam se desenvolver sem a rede mundial de computadores.

\section{Considerações}

Em tempos de pandemia da Covid-19, com o isolamento físico e a restrição de utilização dos espaços públicos, o uso das mídias sociais como meios de socialização entre os sujeitos tem sido observado no cotidiano de muitas pessoas. As mídias sociais organizam as relações sociais no mundo digital e potencializam as interações sociais entre as pessoas que estão conectadas, permitindo que as pessoas se conectem de qualquer lugar, em qualquer tempo e espaço.

As mídias sociais possibilitam um convívio sociointelectual entre os sujeitos. Diversas atividades humanas foram ressignificadas nesse contexto de pandemia, e dentre elas destacamos a ampliação da transmissão de lives via streaming com fins profissionais, acadêmicos e culturais em diversos sites de redes sociais e abertas ao grande público, além de discussões em grupos específicos de sites de redes sociais.

A cultura digital, as tecnologias digitais de rede e os sites de redes sociais estão cada vez mais inseridos nos nossos contextos, sejam eles, familiares, sociais, acadêmicos ou profissionais. A cultura digital é um campo vasto e potente, pois pode estar articulada com qualquer outro campo além das tecnologias, como por exemplo a arte, a educação, a filosofia, a sociologia, etc. Maximiza todos os campos dos saberes dispostos, tanto dentro, quanto fora do espaço escolar justamente por encontrar-se em um lugar que não pode fechar-se para o seu entorno, que o está desafiando os novos jeitos de aprender.

Vivemos e convivemos em uma sociedade desenvolvida sob a influência do paradigma comunicacional de massa, analógico, hierárquico e linear, em que a transmissão das mensagens era apenas de um lado da comunicação, sendo que o outro lado apenas consumia as informações emitidas. No paradigma comunicacional das redes, os sujeitos não só conseguem interagir entre si, como também, produzem conteúdo na internet. A popularização dos sites de redes sociais imprime ao sujeito o potencial de participação e interação social com seus pares, em uma perspectiva de coautoria e inteligência coletiva, e cada vez mais potencializa a socialização dos sujeitos em um mundo digital que acontece em rede e na rede. 


\section{Notas}

1 Entende-se por suporte tecnológico o recurso utilizado para compartilhar uma postagem, como por exemplo: link para um site; link para um vídeo do YouTube; texto; arquivo; imagem; áudio (podcast), entre outros.

2 Sociograma é uma técnica de análise de dados que concentra a atenção sobre a forma como os laços sociais são estabelecidos dentro de qualquer grupo. Disponível em: http://es.wikipedia.org/wiki/Sociograma. Acesso em: 28 jul. 2020.

3 Sociometria do latim socius + metrum, é uma ferramenta analítica para estudo de interações entre grupos. A sociometria pode ser entendida também como o estudo dos vínculos existentes entre indivíduos, enquanto formadores sociais. Disponível em: http://pt.wikipedia.org/wiki/Sociometria. Acesso em: 28 jul. 2020.

4 É importante ressaltar que quando usamos os termos "redes sociais" ou "rede social", estamos nos referindo ao seu sentido estrito, que é o círculo de pessoas do qual fazemos parte. Não usamos o termo "rede social" como sinônimo de "site de rede social" porque esse é a mídia de rede social e não é a rede social, propriamente dita.

\section{Referências}

BOYD, D. M.; ELLISON, N. B. Social network sites: definition, history, and scholarship. Journal of Computer-Mediated Communication, Mediated Communication, Indiana, v. 13, n. 1, Oct. 2007. Disponível em: https://academic.oup.com/jcmc/article/13/1/210/4583062. Acesso em: 27 jul. 2020 .

CAPRA, Fritjof. As conexões ocultas. Ciência para uma vida sustentável. São Paulo: Editora Pensamento - Cultrix, 2002.

CHRISTAKIS, N. A.; FOWLER, J. H. O Poder das Conexões. A importância do networking e como ele molda nossas vidas. Por que os ricos ficam mais ricos? Como achamos e escolhemos nossos companheiros? Por que as emoções são contagiantes? Tradução de Edson Furmankiewicz. Rio de Janeiro: Elsevier, 2010.

CANCLINI, Nestor García. Consumidores e Cidadãos. Conflitos Multiculturais da Globalização. Rio de Janeiro: Editora UFRJ, 2001.

CANCLINI, Nestor García. Democracia e Mass Media. São Paulo: Fundação Memorial da América Latina, 1998. (Coleção Memo).

CASTELLS, Manuel. A era da informação: economia, sociedade e cultura - o poder da identidade. v. 2. 3. ed. São Paulo: Paz e Terra, 1999.

CASTELLS, Manuel. A internet e Sociedade em Rede. In: MORAES, Dênis de (org.). Por uma outra comunicação: mídia, mundialização cultural e poder. 3. ed. Rio de Janeiro: Record, 2005. p. 225-231.

COOLEY, C. H. O significado da comunicação para a vida social. In: CARDOSO, F. H.; IANNI, O. (org.). Homem e sociedade: leituras básicas de sociologia geral. São Paulo: Companhia Editora Nacional, 1975. p. 168-179.

HALL, Stuart. Da diáspora: identidades e mediações culturais. Belo Horizonte: Editora UFMG; Brasília: Representação da UNESCO no Brasil, 2003. 
JENKINS, Henry. Cultura da Convergência. Trad. Susana Alexandria. 2. ed. São Paulo: Aleph, 2009 .

KIRKWOOD, Keith. If They Build It, They Will Come: Creating Opportunities for E-learning Communities of Practice. Language and Learning Skills Unit. Universitas 21 Conference on Elearning and Pedagogy. Guadalajara, Mexico, November, 2006. Disponível em: http://citeseerx. ist.psu.edu/viewdoc/download?doi=10.1.1.130.5695\&rep=rep1\&type=pdf. Acesso em: 12 jun. 2020.

KOEHLER, Cristiane. Interação Social em Rede e nas Redes: contributos para uma educação em rede. 2016. Tese (Doutorado Informática na Educação) - Programa de Pós-Graduação em Informática na Educação, Universidade Federal do Rio Grande do Sul, Porto Alegre, 2016.

LEMOS, André. Cibercultura e Identidade Cultural. Em direção a uma cultura copyleft?. Ensaio apresentado do Fórum Cultural Mundial e no Simpósio Emoção Art. oficial (Itaú Cultural). São Paulo, julho 2004. Disponível em: http://www.facom.ufba.br/ciberpesquisa/andrelemos/copyleft.pdf. Acesso em: 28 jun. 2020.

LEMOS, André. Cibercultura. Alguns Pontos para compreender a nossa época. In: LEMOS, André; CUNHA, Paulo (org.). Olhares sobre a Cibercultura. Porto Alegre: Sulina, 2003. Disponível em: http://www.facom.ufba.br/ciberpesquisa/andrelemos/cibercultura.pdf. Acesso em: 28 jun. 2020.

LEMOS, André. O que é cibercultura? Trecho do debate "Educar na Cultura Digital". Grupo de estudos Educar na Cultura Digital. Bienal de São Paulo. 2010. Disponível em: https://www. youtube.com/watch?v=hCFXsKeIs0w. Acesso em: 27 jul. 2020.

LEMOS, André. Ciberespaço e tecnologias móveis: processos de territorialização e desterritorialização na cibercultura. In: MÉDOLA, Ana Silvia; ARAÚJO, Denise; BRUNO, Fernanda (org.). Imagem, visibilidade e cultura midiática. Porto Alegre: Sulina, 2007. Disponível em: http://www.facom.ufba.br/ciberpesquisa/andrelemos/territorio.pdf. Acesso em: 27 jul. 2020.

LÉVY, Pierre. A inteligência coletiva: por uma antropologia do ciberespaço. 4. ed. São Paulo: Edições Loyola, 2003.

LÉVY, Pierre. Cibercultura. São Paulo: Editora 34, 1999.

MARCON, Karina. Processos Educativos e Comunicacionais na Cibercultura: Explorando Ações de Inclusão Digital. 2008. Dissertação (Mestrado em Educação) - Programa de Pós-Graduação em Educação, Universidade de Passo Fundo, Passo Fundo, 2008.

PARSONS, T.; SHILL, E. A interação social. In: CARDOSO, F. H.; IANNI, O. (org.). Homem e sociedade: leituras básicas de sociologia geral. São Paulo: Companhia Editora Nacional, 1975. p. 125-127.

PRIMO, A. T. Interação mediada por computador: a comunicação e a educação a distância segundo uma perspectiva sistêmico-relacional. Tese (Doutorado em Informática na Educação), Programa de Pós-Graduação em Informática na Educação, Universidade Federal do Rio Grande do Sul, Porto Alegre, 2003. Disponível em: http://www.lume.ufrgs.br/handle/10183/6959. Acesso em: 28 jul. 2020.

RECUERO, R. Redes sociais na internet. Porto Alegre: Sulina, 2009. (Coleção Cibercultura). 
RECUERO, R. Conversação em rede: comunicação mediada pelo computador e redes sociais na internet. 2. ed. Porto Alegre: Sulina, 2014.

RECUERO, R.; BASTOS, M.; ZAGO, G. Análise de redes para mídia social. Porto Alegre: Sulina, 2015. (Coleção Cibercultura).

REID, E. Electropolis: communication and community on internet relay chat. 1991. Honours thesis - University of Melbourne, Meulborne, 1991.

RÜDIGER, Francisco. Elementos para a crítica da cibercultura: sujeito, objeto e interação. São Paulo: Hacker Editores, 2002.

SANTAELLA, L.; LEMOS, R. Redes sociais digitais: a cognição conectiva do Twitter. São Paulo: Paulus, 2010. (Coleção Comunicação).

SILVA, M. Sala de aula interativa: educação, comunicação, mídia clássica, internet, tecnologias digitais, arte, mercado, sociedade, cidadania. 5. ed. São Paulo: Loyola, 2010.

WASSERMAN, S.; FAUST, K. Social Network Analysis. Methods and Applications. Cambridge, UK: Cambridge University Press, 1994.

WATZLAWICK, P.; BEAVIN, J. H.; JACKSON, D. D. Pragmática da comunicação humana. 11. ed. São Paulo: Cultrix, 2000. 